\title{
GAYA HIDUP, RIWAYAT PENGGUNAAN KONTRASEPSI, DAN PENGETAHUAN KANKER SERVIKS PADA PASIEN KANKER SERVIKS
}

\author{
Adriana Mehta, Yati Afiyanti \\ Keilmuan Keperawatan Fakultas IImu Keperawatan Universitas Indonesia \\ Kampus FIK UI, Depok, Jawa Barat. \\ E-mail: jonunganhosaimnida@yahoo.com, yatikris@ui.ac.id
}

\begin{abstract}
ABSTRAK
Tujuan penelitian: Penelitian ini bertujuan mengidentifikasi faktor predisposisi yang berhubungan dengan kejadian kanker serviks. Metode: Rancangan penelitian yang digunakan yakni restrospektif noneksperimental dengan pendekatan potong lintang dan besar sampel 80 responden yang dipilih dengan menggunakan teknik consecutive sampling. Hasil: Hasil analisis penelitian menunjukkan bahwa tidak ditemukan hubungan signifikan antara perilaku seksual, perilaku merawat kebersihan alat kelamin, riwayat penggunaan kontrasepsi, dan pengetahuan kanker serviks terhadap kejadian kanker serviks. Diskusi: Hasil penelitian menyarankan diperlukannya pembahasan/penelitian dengan studi kohort lebih lanjut mengenai hubungan faktor risiko kanker serviks terhadap kejadian kanker serviks. Simpulan: Gaya hidup, riwayat penggunaan kontrasepsi, dan pengetahuan tidak berhubungan dengan tingkat kejadian kanker serviks.
\end{abstract}

Kata Kunci: kanker serviks, kontrasepsi, pengetahuan kanker serviks, perilaku merawat kebersihan alat kelamin, perilaku seksual.

\begin{abstract}
Objective: This study aimed to identify predisposing factors related to the prevalence of cervical cancer. Method: This study was retrospective non experimental with cross-sectional design with a sample size of 80 respondents taken using consecutive sampling. Result: There was no significant correlation of sexual behavior, personal hygiene practice, history of contraception use, and knowledge of cervical cancer with the incidence of cervical cancer. Discussion: The results suggest the need for using further cohort study to find out the correlation between risk factors of cervical cancer and the incidence of cervical cancer). Conclusion: There are no correlation of life style, history of contraseption use, and knowledge with the incidence of cervical cancer.
\end{abstract}

Keywords: cervical cancer, contraceptive, knowledge, personal hygiene practice, sexual behavior.

\section{LATAR BELAKANG}

Menurut data Kementerian Kesehatan tahun 2007, kanker payudara menduduki peringkat satu sebagai kanker paling banyak diderita perempuan Indonesia yakni 18 persen dan kanker serviks sebanyak sembilan persen (Permanasari, 2012). Angka ini menurun dibandingkan tahun 2006, tetapi sejak tahun 2008 didapatkan bahwa angka kejadian ini pun menunjukkan peningkatan per tahunnya. Deteksi dini kanker serviks secara berkala pun belum efektif dalam menurunkan angka kejadian penyakit ini. Kementerian Kesehatan mengemukakan bahwa upaya pencegahan yang efektif adalah menghindari segala faktor risiko kanker tersebut. Kejadian kanker serviks dipengaruhi oleh multifaktor. 
Hasil studi mendapatkan bahwa penyebab kasus perempuan terkena kanker serviks terbanyak yakni berkaitan dengan hubungan seksual dini dan banyaknya jumlah pasangan seksual yang dimiliki (Fulton, Langhorne, dan Otto, 2007). Data ini tidak jauh berbeda dengan yang terjadi di Indonesia, yakni survei yang dilakukan BKKBN tahun 2008 menyebutkan 63 persen remaja telah melakukan hubungan seksual pranikah (Harmandini, 2011). Hal ini tentu menguatkan kemungkinan risiko lebih tinggi kejadian kanker serviks pada perempuan Indonesia akibat riwayat perilaku seksual yang buruk.

Jenis kontrasepsi dan lama penggunaan kontrasepsi juga dikatakan menjadi faktor risiko kejadian kanker serviks pada perempuan (Lumsden \& Hickey, 2000). Penelitian Castellagué (2011) menyatakan perempuan akseptor IUD memiliki risiko 50 persen untuk terkena kanker serviks dibandingkan dengan yang tidak menggunakan. Penggunaan kontrasepsi oral menunjukkan risiko lebih tinggi kanker serviks dibandingkan penggunaan jenis yang lain. Hasil penelitian pun mengemukakan bahwa perempuan yang menggunakan kontrasepsi lebih dari delapan tahun, 15 persen berisiko dari perempuan yang tidak menggunakannya (Cuzick, 1996).

Upaya preventif sederhana yakni menjaga kehigienisan genital diabaikan oleh kebanyakan perempuan. Beragamnya tindakan dan medikasi dalam rangka meningkatkan kehigienisan genital bagi perempuan, justru tidak disertai dengan pemahaman dalam melakukan tindakan tersebut. Hasil studi Menard (2008) menunjukkan bahwa perempuan menjaga kehigienisan genital sebagai upaya untuk menjaga tingkat kepuasan dalam hubungan seksual bagi pasangannya serta bentuk dari kebudayaan semata. Hasil penelitian pun mengemukakan terjadinya peningkatan intensitas pada penggunaan vaginal douching pada perempuan dan berdampak peningkatan risiko penyakit seksual hingga mengalami kanker serviks (Brotman, 2008).

Berbagai kondisi tersebut tidak dipungkiri dipengaruhi oleh tingkat pendidikan dan pengetahuan kanker serviks dalam konteks ini yakni perempuan. Perempuan dengan latar belakang pendidikan tinggi, disimpulkan kemungkinan memiliki pengetahuan kanker serviks lebih baik dibandingkan pendidikan yang rendah (Ralston, 2003). Namun, peningkatan kasus kejadian kanker serviks di Indonesia setiap tahunnya menunjukkan kemungkinan masih rendahnya tingkat pengetahuan dan pemahaman tersebut. Hal ini menunjukkan bahwa kejadian kanker serviks dipengaruhi multifaktor. Berbagai faktor tersebut ataupun lainnya diketahui berpengaruh pada tingginya angka kejadian kanker serviks di Indonesia. Oleh karena itu, penelitian ini akan mempelajari berbagai faktor risiko yang memengaruhi kejadian kanker serviks pada perempuan.

\section{METODE}

Rancangan yang digunakan yakni retrospektif non-eksperimen dengan pendekatan potong lintang. Sampel penelitian ini adalah beberapa perempuan yang didiagnosis kanker serviks berdasarkan rekam medis di Rumah Sakit Kanker Dharmais serta memenuhi kriteria inklusi yang ditetapkan. Responden dipilih dengan teknik consecutive sampling. Responden yang bersedia diberi waktu untuk mengisi kuesioner. Instrumen yang digunakan terdiri enam bagian. Pertanyaan tertutup digunakan pada seluruh bagian kuesioner dan penggunaan Skala Guttman pada bagian perilaku merawat kebersihan alat kelamin dan pengetahuan kanker serviks.

Analsis data menggunakan uji statistik proporsi dan penyajian hasil menggunakan persentase. Variabel usia responden berbentuk data numerik, maka uji statistik nilai 
mean, nilai tengah median, termasuk standar deviasi dipilih untuk mengetahui distribusi variabel tersebut. Analisis dilanjutkan untuk melihat hubungan antar-dua variabel. Uji statistik kai kuadrat (chi square) digunakan dalam analisis bivariat penelitian ini.

\section{HASIL}

Sebanyak 80 pasien yang mengalami neoplasia servikal menjadi responden dalam penelitian ini. Berdasarkan tipe histologi, sebanyak 69 responden mengalami kanker serviks dengan tipe histologi karsinoma sel skuamosa. Jumlah ini lebih banyak dibandingkankankerserviksadenokarsinoma servikal dan cervical intraepithelial neoplasia (CIN), yakni sebanyak delapan dan tiga responden. Tabel 1 menunjukkan gambaran karakteristik demografi responden. Riwayat pendidikan responden sebanyak 60 persen berpendidikan Sekolah Menengah Pertama. Sebanyak 66,3 persen responden tidak memiliki pekerjaan, dan hampir semua responden, yaitu 97,5 persen memiliki paritas multipara. Lebih dari 90 persen responden tidak memiliki riwayat keluarga dengan kanker dan tidak memiliki riwayat kanker sebelumnya. Berkaitan dengan pemeriksaan papsmear, sebanyak $77,5 \%$ responden tidak pernah melakukan papsmear.

Tabel 1 Karakteristik Demografi Responden $(n=80)$

\begin{tabular}{|c|c|c|}
\hline Variabel & Frekuensi & Persentase \\
\hline $\begin{array}{l}\text { Pendidikan Terakhir: } \\
\text { Dasar } \\
\text { Menengah } \\
\text { Atas }\end{array}$ & $\begin{array}{l}19 \\
48 \\
13\end{array}$ & $\begin{array}{l}23,8 \\
60,0 \\
16,3\end{array}$ \\
\hline $\begin{array}{l}\text { Pekerjaan } \\
\text { Tidak Bekerja } \\
\text { Bekerja }\end{array}$ & $\begin{array}{l}53 \\
27\end{array}$ & $\begin{array}{l}66,3 \\
33,8\end{array}$ \\
\hline $\begin{array}{l}\text { Status Sosial Ekonomi } \\
\geq \operatorname{Rp} 2.200 .000,00 \\
<\operatorname{Rp} 2.200 .000,00\end{array}$ & $\begin{array}{l}43 \\
37\end{array}$ & $\begin{array}{l}53,8 \\
46,3\end{array}$ \\
\hline $\begin{array}{l}\text { Paritas } \\
\text { Primipara } \\
\text { Multipara }\end{array}$ & $\begin{array}{c}2 \\
78\end{array}$ & $\begin{array}{c}2,5 \\
97,5\end{array}$ \\
\hline $\begin{array}{l}\text { Keturunan (Hereditas) } \\
\text { Tidak terdapat riwayat keturunan anggota keluarga dengan kanker } \\
\text { Terdapat riwayat keturunan anggota keluarga dengan kanker }\end{array}$ & $\begin{array}{c}74 \\
6\end{array}$ & $\begin{array}{c}92,5 \\
7,5\end{array}$ \\
\hline $\begin{array}{l}\text { Kebiasaan Merokok } \\
\text { Tidak } \\
\text { Ya }\end{array}$ & $\begin{array}{c}76 \\
4\end{array}$ & $\begin{array}{c}95,0 \\
5,0\end{array}$ \\
\hline $\begin{array}{l}\text { Pemeriksaan Pap Smear } \\
\text { Tidak Pernah } \\
\text { Jarang } \\
\text { Sering }\end{array}$ & $\begin{array}{c}62 \\
15 \\
3\end{array}$ & $\begin{array}{c}77,5 \\
18,8 \\
3,8\end{array}$ \\
\hline $\begin{array}{l}\text { Riwayat Kanker Sebelumnya } \\
\text { Tidak } \\
\text { Ya }\end{array}$ & $\begin{array}{c}75 \\
5\end{array}$ & $\begin{array}{c}93,8 \\
6,3\end{array}$ \\
\hline $\begin{array}{l}\text { Riwayat Penggunaan Kontrasepsi } \\
\text { Tidak Pernah } \\
\text { Pernah }\end{array}$ & $\begin{array}{l}10 \\
70\end{array}$ & $\begin{array}{l}12,5 \\
87,5\end{array}$ \\
\hline
\end{tabular}


Tabel 2 Distribusi Responden Menurut Faktor Predisposisi dan Kejadian Kanker Serviks

\begin{tabular}{|c|c|c|c|c|c|c|c|}
\hline \multirow[t]{3}{*}{ Faktor Predisposisi } & \multicolumn{4}{|c|}{ Kejadian Kanker Serviks } & \multirow{2}{*}{\multicolumn{2}{|c|}{ Total }} & \multirow{3}{*}{$\begin{array}{c}\text { Nilai } p \\
(\alpha=0,05)\end{array}$} \\
\hline & \multicolumn{2}{|c|}{ Prakanker } & \multicolumn{2}{|c|}{ Kanker Serviks } & & & \\
\hline & $\mathbf{n}$ & Persentase & $\mathrm{n}$ & Persentase & $\mathbf{n}$ & Persentase & \\
\hline $\begin{array}{l}\text { Jumlah Mitra Seksual } \\
1 \\
>1\end{array}$ & $\begin{array}{l}3 \\
0\end{array}$ & $\begin{array}{c}4,1 \\
0\end{array}$ & $\begin{array}{c}7,1 \\
6\end{array}$ & $\begin{array}{l}95,9 \\
100\end{array}$ & $\begin{array}{c}74 \\
6\end{array}$ & $\begin{array}{l}100 \\
100\end{array}$ & 1,000 \\
\hline $\begin{array}{l}\text { Usia Melakukan } \\
\text { Hubungan Seksual } \\
\text { Vaginal Pertama }\end{array}$ & & & & & & & \\
\hline $\begin{array}{l}>15 \text { tahun } \\
\geq 15 \text { tahun }\end{array}$ & $\begin{array}{l}3 \\
0\end{array}$ & $\begin{array}{c}3,8 \\
0\end{array}$ & $\begin{array}{c}75 \\
2\end{array}$ & $\begin{array}{l}96,2 \\
100\end{array}$ & $\begin{array}{c}78 \\
2\end{array}$ & $\begin{array}{l}100 \\
100\end{array}$ & 1,000 \\
\hline $\begin{array}{l}\text { Riwayat Penyakit } \\
\text { Kelamin }\end{array}$ & & & & & & & \\
\hline $\begin{array}{l}\text { Tidak } \\
\text { lya }\end{array}$ & $\begin{array}{l}3 \\
0\end{array}$ & $\begin{array}{c}4,0 \\
0\end{array}$ & $\begin{array}{c}72 \\
5\end{array}$ & $\begin{array}{l}96,0 \\
100\end{array}$ & $\begin{array}{c}38 \\
5\end{array}$ & $\begin{array}{l}100 \\
100\end{array}$ & 1,000 \\
\hline $\begin{array}{l}\text { Perilaku Merawat } \\
\text { Kebersihan Alat } \\
\text { Kelamin }\end{array}$ & & & & & & & 0,242 \\
\hline $\begin{array}{l}\text { Baik } \\
\text { Kurang Baik }\end{array}$ & 3 & 7,1 & 39 & 92,9 & 42 & 100 & \\
\hline $\begin{array}{l}\text { Pengetahuan Kanker } \\
\text { Serviks } \\
\text { Tingai }\end{array}$ & $\begin{array}{l}3 \\
0\end{array}$ & $\begin{array}{c}6,7 \\
0\end{array}$ & $\begin{array}{l}42 \\
35\end{array}$ & $\begin{array}{c}93,3 \\
100\end{array}$ & $\begin{array}{l}45 \\
35\end{array}$ & $\begin{array}{l}100 \\
100\end{array}$ & 0,252 \\
\hline $\begin{array}{l}\text { Tinggi } \\
\text { Rendah }\end{array}$ & 0 & 0 & 35 & 100 & 35 & 100 & \\
\hline
\end{tabular}

Tabel 3 Distribusi Responden Menurut Riwayat Penggunaan Kontrasepsi dan Kejadian Kanker Serviks $(n=70)$

\begin{tabular}{|c|c|c|c|c|c|c|c|}
\hline \multirow{3}{*}{$\begin{array}{c}\text { Riwayat Penggunaan } \\
\text { Kontrasepsi }\end{array}$} & \multicolumn{4}{|c|}{ Kejadian Kanker Serviks } & \multirow{2}{*}{\multicolumn{2}{|c|}{ Total }} & \multirow{3}{*}{$\begin{array}{c}\text { Nilai } p \\
(\alpha=0,05)\end{array}$} \\
\hline & \multicolumn{2}{|c|}{ Prakanker } & \multicolumn{2}{|c|}{ Kanker Serviks } & & & \\
\hline & $\mathbf{n}$ & Persentase & $\mathbf{n}$ & Persentase & $\mathbf{n}$ & Persentase & \\
\hline $\begin{array}{l}\text { Jenis Kontrasepsi } \\
\text { Metode Hormonal } \\
\text { Metode Alat Kontrasepsi } \\
\text { Dalam Rahim }\end{array}$ & $\begin{array}{l}2 \\
1\end{array}$ & $\begin{array}{l}3,8 \\
6,3\end{array}$ & $\begin{array}{l}52 \\
15\end{array}$ & $\begin{array}{l}96,2 \\
93,7\end{array}$ & $\begin{array}{l}54 \\
16\end{array}$ & $\begin{array}{l}100 \\
100\end{array}$ & 0,559 \\
\hline $\begin{array}{l}\text { Lama Penggunaan } \\
\text { Kontrasepsi } \\
<5 \text { tahun } \\
5-8 \text { tahun } \\
>8 \text { tahun }\end{array}$ & $\begin{array}{l}1 \\
2 \\
0\end{array}$ & $\begin{array}{c}4,0 \\
6,9 \\
0\end{array}$ & $\begin{array}{l}24 \\
27 \\
16\end{array}$ & $\begin{array}{l}96,0 \\
93,1 \\
100\end{array}$ & $\begin{array}{l}25 \\
29 \\
16\end{array}$ & $\begin{array}{l}100 \\
100 \\
100\end{array}$ & 0,548 \\
\hline $\begin{array}{l}\text { Riwayat Pemeriksaan } \\
\text { Kontrasepsi } \\
\text { Tidak Pernah } \\
\text { Jarang } \\
\text { Sering }\end{array}$ & $\begin{array}{l}2 \\
1 \\
0\end{array}$ & $\begin{array}{c}5,0 \\
7,7 \\
0\end{array}$ & $\begin{array}{l}38 \\
12 \\
17\end{array}$ & $\begin{array}{l}95,0 \\
92,3 \\
100\end{array}$ & $\begin{array}{l}28 \\
12 \\
17\end{array}$ & $\begin{array}{l}100 \\
100 \\
100\end{array}$ & 0,555 \\
\hline
\end{tabular}


Mayoritas responden yang didiagnosis kanker serviks pada penelitian ini memiliki jumlah mitra seksual satu (monogami), mengalami hubungan seksual vaginal, dan tidak pernah memiliki riwayat penyakit pada daerah kelamin (Tabel 2). Berdasarkan hasil uji statistik disimpulkan bahwa tidak terdapat hubungan bermakna perilaku seksual terhadap kejadian kanker serviks. Kesimpulan ini pun serupa dengan hubungan perilaku merawat kebersihan alat kelamin dan pengetahuan kanker serviks terhadap kejadian kanker serviks.

Penggunaan jenis kontrasepsi hormonal pada responden yang didiagnosis kanker serviks lebih banyak dibandingkan metode kontrasepsi IUD, yakni 52 (96,2 persen) responden. Hasil analisis hubungan menunjukkan tidak ditemukan adanya hubungan antara jenis kontrasepsi dan jangka waktu penggunaan kontrasepsi terhadap kejadian kanker serviks. Tabel 3 menunjukkan distribusi responden menurut riwayat penggunaan kontrasepsi dan kejadian kanker serviks. Kesimpulan serupa juga dinyatakan pada ada/tidak hubungan riwayat pemeriksaan kontrasepsi secara berkala oleh responden terhadap kejadian kanker serviks.

\section{DISKUSI}

Mayoritas responden yang mengalami kanker serviks memiliki jumlah mitra seksual satu (monogami) dan tidak pernah didiagnosis penyakit kelamin sebelumnya. Hasil penelitian Castellsagué (2011) menunjukkan hasil yang sama untuk kedua variabel, yakni jumlah mitra seksual dan usia melakukan hubungan seksual vaginal pertama. Mayoritas responden tidak pernah memiliki riwayat genital warts. Perbedaan tampak pada distribusi responden menurut jumlah mitra seksual, yakni riwayat mitra seksual pada kelompok kasus maupun kontrol berjumlah enam sampai 19.
Berdasarkan dimensi sosiokultural, seksualitas dipengaruhi oleh norma dan peraturan kultural yang menentukan perilaku yang diterima dalam kultur. Keberagaman kultural secara global menciptakan variabilitas yang sangat luas dalam norma seksual, mencakup cara dan perilaku dalam aktivitas seksualual hingga sanksi serta larangan dalam perilaku seksual (Potter dan Perry, 2005). Perbedaan karakteristik sosio demografik responden pada penelitian ini dengan penelitian sebelumnya kemungkinan menjadi dasar keberagaman hasil.

Survei definitif dan komprehensif tentang keyakinan dan praktik seksual di Amerika yang dilakukan oleh peneliti Universitas Chicago menunjukkan bahwa seorang individu dipengaruhi oleh jaringan sosial mereka dan cenderung untuk melakukan apa yang digariskan oleh lingkungan sosial mereka (Potter dan Perry, 2005). Hal ini menunjukkan bahwa individu dan masyarakat memiliki peranan yang kuat dalam membentuk nilai dan sikap seksual, membentuk atau menghambat perkembangan dan ekspresi seksual anggotanya, hingga pembentukan norma dan aturan. Norma dan aturan tersebut menjadi dasar berpikir dan pilihan perilaku seksual individu, mencakup bagaimana seseorang menemukan pasangan hidupnya, seberapa sering mereka melakukan hubungan seksual, dan apa yang mereka lakukan ketika melakukan hubungan seksual.

Tidak adanya hubungan perilaku seksual terhadap kejadian kanker serviks pada penelitian ini tidak sejalan dengan penelitian Cuzick, dkk. (1996) yang menyimpulkan bahwa ada perbedaan signifkan perilaku seksual dengan kejadian kanker serviks. Seorang perempuan yang telah aktif dalam hubungan seksual memang tidak menutup kemungkinan akan terinfeksi HPV (Bosch, 2008). Hal ini disebabkan beberapa tipe HPV merupakan etiologi 
penyakit kutil pada area genital baik laki-laki maupun perempuan, seperti genital warts atau condyloma acuminatum (American Cancer Society, 2012). Namun, American Cancer Society (2012) menegaskan bahwa infeksi HPV dari seseorang kepada orang lain dapat terjadi bukan selalu diakibatkan hubungan seksual, melainkan frekuensi terjadinya kontak fisik (skin-to-skin) antara area tubuh yang positif HPV (seperti anus, mulut, maupun genital).

Paparan dan infeksi HPV yang terus menerus itulah yang lebih diyakini meningkatkan risiko terjadinya lesi servikal hingga kepada tahap keganasan. Hal ini didasarkan bahwa progresi infeksi HPV menjadi kanker serviks harus melalui empat tahapan, yakni transmisi HPV, infeksi HPV akut, infeksi HPV persisten yang memicu perubahan menjadi pra-kanker, dan terakhir menjadi karsinoma in situ (Vesco, 2011). Oleh karena itu, frekuensi paparan infeksi HPV menjadi kemungkinan faktor yang berhubungan dibanding perilaku seksual itu sendiri.

Riwayat aktivitas seksual pasangan memungkinkan untuk turut berperan penting dalam infeksi HPV. Copper, dkk. (2007) mengungkapkan perilaku seksual pasangan menunjukkan pengaruh lebih terhadap kejadian kanker serviks dibandingkan dengan perilaku seksual perempuan itu sendiri. Riwayat menggunakan kondom, penyakit menular seksual, serta jumlah mitra seksual yang dimiliki pasangan sebelumnya kemungkinan memiliki peranan terhadap hubungan perilaku seksual dengan kejadian kanker serviks. Waller (2004) pun menyatakan bahwa ada kemungkinan hubungan prevalensi HPV dan aktivitas seksual perempuan dilihat pada perilaku pasangannya, yakni perempuan dengan jumlah mitra seksual satu dapat dengan mudah kontak dengan HPV jika riwayat seksual pasangannya aktif.

\section{Mayoritas}

responden

yang didiagnosis kanker serviks menunjukkan perilaku merawat kebersihan alat kelamin yang kurang baik dibandingkan perilaku yang baik. Penelitian sebelumnya mengenai perilaku merawat kebersihan alat kelamin dengan kejadian kanker serviks minim. Hal ini menyebabkan dasar analisis hubungan tersebut masih belum jelas. Penelitian mengenai perilaku merawat kebersihan alat kelamin mayoritas berfokus pada hubungan penggunaan, seperti vaginal douching, sebagai salah satu bentuk perilaku merawat kebersihan alat kelamin terhadap kejadian kanker serviks. Hal ini seperti pada fokus penelitian yang dilakukan oleh Menard (2008) yang menyimpulkan bahwa ada peningkatan risiko kanker serviks dan infeksi servikal pada perempuan berhubungan dengan intravaginal practice dan vaginal douching.

Haverkos (2000) menjelaskan bahwa hubungan perilaku merawat kebersihan alat kelamin terhadap risiko kanker serviks lebih berhubungan dengan bahan kimia yang terkandung dalam produk yang digunakan dalam perilaku tersebut. Hal ini disebabkan komponen kimia kemungkinan dapat menjadi faktor yang menyebabkan iritasi pada vagina dan serviks. Kemudian, hal tersebut juga kemungkinan dapat memfasilitasi transmisi agen infeksius.

Pengetahuan responden mengenai kanker serviks menunjukkan bahwa responden yang didiagnosis kanker serviks memiliki pengetahuan yang tinggi mengenai kanker serviks dibandingkan pengetahuan yang rendah. Hasil ini sejalan dengan hasil penelitian Ralston (2003). Persamaan hasil distribusi proporsi mengenai tingkat pengetahuan kanker serviks ini kemungkinan dipengaruhi oleh sosio demografi dan akulturasi karakteristik (Ralston, 2003). Tingkat pendidikan yang lebih tinggi meningkatkan pengetahuan mengenai 
kanker serviks. Mayoritas responden pada penelitian ini telah menyelesaikan tingkat pendidikan hingga pada jenjang menengah. Karakteristik ini pun ditunjukkan pada penelitian sebelumnya.

Pada penelitian tidak ada hubungan antara tingkat pengetahuan kanker serviks dengan kejadian kanker serviks. Ini berbeda dengan kesimpulan pada penelitian Ralston (2003). Analisis Ralston lebih lanjut menjabarkan pengetahuan tersebut mendorong ada atau tidaknya kepedulian perempuan terhadap faktor risiko hingga pencegahan kanker serviks. Semakin tinggi tingkatan pengetahuan seseorang, maka perilaku yang dibentuk semakin kokoh atau langgeng dibanding dengan yang tidak didasari pengetahuan. Konsep tersebut sejalan dengan kesimpulan Ralston dalam penelitiannya. Hubungan tingkat pengetahuan mengenai kanker serviks mungkin dapat ditunjukkan dari hubungan perilaku yang berkaitan dengan kejadian kanker serviks itu sendiri, seperti perilaku melakukan pemeriksaan pap smear pada perempuan, dibandingkan dengan skor pengetahuan sesorang perempuan mengenai kanker serviks.

Studi Ingledue, dkk. (2004) menyimpulkan bahwa rendahnya tingkat pengetahuan dan kesalahpahaman mengenai hubungan faktor risiko, akan memengaruhi perilaku individu perempuan dalam pencegahan kanker serviks. Hal tersebut diyakini dengan adanya seekingbehaviour individu yang tinggi seperti untuk pemeriksaan dini kanker serviks kemungkinan memengaruhi risiko kejadian kanker serviks (Pearlman, dkk., 1999). Meskipun begitu, pengalaman individu tidak dipungkirimemengaruhipengetahuan. Setiap kejadian yang dialami oleh individu dapat menjadi pengetahuan dan pembelajaran bagi individu (Notoatmodjo, 2007). Jika individu mengalami suatu masalah yang sama sebelumnya, individu tersebut akan mendapatkan pemahaman yang lebih baik. Sampel studi ini adalah individu yang pernah atau tengah mengalami masalah, yakni kanker serviks. Karakteristik sampel ini berbeda dengan penelitian yang dilakukan oleh Ralston.

Kesimpulan sama dinyatakan terhadap hasil analisis hubungan riwayat penggunaan kontrasepsi dengan kejadian kanker serviks. Studi penelitian Cuzick, dkk (1996) bahwa hubungan penggunaan kontrasepsi terutama jenis oral belum jelas tingkat kemaknaannya. Secara keseluruhan, responden yang pernah menggunakan kontrasepsi tidak menunjukkan risiko yang lebih tinggi atau rendah dibanding yang tidak menggunakan. Wanita yang menggunakan kontrasepsi hormonal dalam rentang waktu dua sampai delapan tahun memiliki risiko sama dengan yang tidak menggunakan (Cuzick, 1996).

Menurut American Cancer Society (2012), risiko kanker serviks akan meningkat dua kali pada wanita yang menggunakan kontrasepsi, terutama hormonal. Namun, peluang atau risiko tersebut akan menurun bersamaan dengan pemberhentian penggunaan tersebut. Hal tersebut menunjukkan bahwa periode ketika tidak menggunakan kontrasepsi, baik berhenti sementara maupun berhenti menjadi faktor kemungkinan yang memengaruhi hubungan durasi penggunaan kontrasepsi dengan kejadian kanker serviks.

Studi penelitian mengungkapkan penggunaan kontrasepsi oral tidak meningkatkan risiko mengalami kejadian kanker serviks, jika infeksi HPV pun absen atau tidak ada. Infeksi HPV menunjukkan adanya viral DNA yang kemungkinan berkembang menjadi kanker serviks (IARC, 2005). Durasi penggunaan kontrasepsi yang lama meningkatkan peluang empat kali risiko kanker serviks pada wanita yang telah 
positif terdapat DNA HPV (infeksi HPV). Dengan demikian, jumlah atau paparan HPV kemungkinan menjadi faktor utama yang memengaruhi ada atau tidaknya pengaruh atau hubungan riwayat penggunaan dan durasi penggunaan terhadap kejadian kanker serviks.

Kesimpulan serupa juga dijabarkan dalam penelitian Castellsagué (2011) mengenai hubungan penggunaan kontrasepsi IUD terhadap risiko kanker serviks. Hasil tersebut mungkin didasarkan bahwa penggunaan kontrasepsi IUD lebih memengaruhi dalam proses progresi infeksi HPV pada individu yang telah positif terpapar infeksiHPV, bukankepadakejadian prevalensi infeksi HPV. Dengan kata lain, kontrasepsi IUD justru sebagai kofaktor pelindung dalam karsinogenesis servikal. Mekanisme tersebut yakni kontrasepsi IUD akan menginduksi reaktif dan respons inflamasi pada endometrium, kanal endoservikal, dan serviks. Hal ini akan mengubah status imun mukosa lokal ketika IUD dimasukan yang kemudian diyakini lebih memengaruhi ketika proses progresi infeksi HPV pada individu yang positif terpapar HPV hingga menjadi keganasan (Castellsagué, 2011). Selain itu, adanya prosedur eliminasi lesi servikal saat kontrasepsi IUD dimasukkan, menunjukkan bahwa hubungan kontrasepsi IUD dan durasi penggunaan terhadap kejadian kanker serviks tidak bermakna.

Menurut Haverkos (2000), penggunaan kontrasepsi dengan sistem pelindung (seperti, kondom) mungkin bertindak sebagai proteksi dalam penyebaran atau transmisi penyakit seksual. Hal ini tidak dipungkiri dapat bertindak sebagai proteksi bagi transmisi HPV penyebab kanker serviks. Peranan yang berbeda diketahui pada penggunaan metode kontrasepsi tanpa pelindung, seperti IUD maupun hormonal. Kemungkinan terhadap penyebaran atau transmisi risiko penyebab penyakit seksual pada penggunaan metode pun lebih tinggi (Haverkos, 2000). Oleh karena itu, perlu ditelusuri lebih jauh terutama mengenai faktor eksternal lain yang memengaruhi setiap faktor risiko dengan kejadian kanker serviks, seperti status paparan atau infeksi HPV, riwayat perilaku seksual pasangan, hingga durasi sementara pada penggunaan kontrasepsi terhadap kejadian kanker serviks.

\section{SIMPULAN}

Gaya hidup, riwayat penggunaan kontrasepsi, dan pengetahuan kanker serviks tidak berhubungan terhadap kejadian kanker serviks. Penelitian ini dapat menjadi bahan pertimbangan untuk pengembangan pengetahuan lingkup keilmuan kesehatan dan keperawatan, khususnya lingkup keperawatan ginekologi dan onkologi, melalui peningkatkan pembahasan materi mengenai penyebab utama kanker serviks, yakni infeksi virus HPV. Selanjutnya, faktor risiko, dan kaitan faktor tersebut dalam infeksi virus HPV. Perlu penelitian lebih lanjut mengenai hubungan faktor risiko kanker serviks terhadap kejadian kanker serviks dengan studi kohort, sehingga memungkinkan untuk memberikan bukti hubungan sebab akibat yang lebih baik.

\section{DAFTAR PUSTAKA}

American Cancer Society. (2012). "Cervical

Cancer". www.cancer.org. (Diakses tanggal 24 September 2012.

Bosch, X. dkk. (2008). "Epidemiology and Natural History of Human Papillomavirus Infections and Type-Specific Implications in Cervical Neoplasia". Vaccine, 10, hlm.: 10-16.

Brotman, R.M. (2008). Dissertations and Theses: Prospective Studies of Vaginal Douching and Bacterial Vaginosis. Baltimore, Maryland: ProQuest LLC. 
Castellsagué, X. dkk. (2011). "Intrauterine Device Use, Cervical Infection with Human Papillomavirus, and Risk of Cervical Cancer: A Pooled Analysis of 26 Epidemiological Studies". Lancet oncol, 12, hlm.: 1023-1031.

Cuzick, J., Sasieni, P., dan Singer, A. (1996).

"Risk Factors for Invasive Cervix in Young Women". European Journal of Cancer, Vol. 32A, No.3, hlm.: 836-841.

Fulton, J.S., Langhorne, M.E., dan Otto, S.E. (2007). Oncology nursing. St. Louis: Mosby Elsevier.

Harmandini, F. (2011). "Pengidap Kanker Serviks Semakin Muda". http://female. kompas.com/read/2011/11/09/12462441/ Pengidap.Kanker.Serviks.Semakin. Muda\# (Diakses tanggal 3 Oktober 2012). Haverkos, H. dkk. (2000). "The Cause of Invasive Cervical Cancer Could be Multifactorial". Biomed \& Pharmacother, 54, hlm.: 54-59.

Ingledue, K. dkk. (2004). "College Women's Knowledge, Perceptions, and Preventive Behaviors Regarding Human Papillomavirus Infection \& Cervical Cancer". American Journal of Health Studies, 19, hlm.: 33-34.

International Agency For Research on Cancer (IARC). (2005). IARC Handbook of Cancer Prevention. Geneva: IARC Press.

Lumsden, M.A. \& Hickey, M. (2000). Complete Women's Health. Hammersmith, London: Thorsons.
Menard, J.M. (2008). Dissertations and Theses: The Social Context of Cervical Cancer Knowledge and Prevention among Haitian Immigrant Women. South Florida: University of South Florida (USF). Notoatmodjo, S. (2007). Kesehatan Masyarakat IImu dan Seni. Jakarta: Rineka Cipta.

Pearlman, D.N. dkk. (1999). "Screening for Breast and Cervical Cancers: The Importance of Knowledge and Perceived Cancer Survivability". Women Health, 28, hlm.: 93-112.

Permanasari, I. (2012). "Kanker Serviks, Ancaman Besar Bagi Perempuan". h t t p://health.kompas.com/ $\mathrm{read} / 2012 / 04 / 18 / 16550850 /$ Kanker. Serviks.Ancaan.Besar.Bagi.Perempuan. Diakses tanggal 3 Oktober 2012.

Potter, P.A. \& Perry, A.G. (2005). Fundamentals of Nursing. St. Louis: Elsevier, Mosby.

Ralston, J.D. dkk. (2003). "Knowledge of Cervical Cancer Risk Factors among Chinese immigrants in Seattle". Journal of Community Health, Vol. 28, No. 1-41.

Vesco, K.K. dkk. (2011). "Risk Factors and Other Epidemiologic Considerations for Cervical Cancer Screening: A Narrative Review for The U.S. Preventive Services Task Force". Ann Intern Med, 155, hlm.: 698-705.

Waller, J. dkk. (2004). "Beliefs About The Risk Factors for Cervical Cancer in A British Population Sample". Preventive Medicine, 38, hlm.: 745-753. 